\title{
Penerapan language experience approach melalui cerita budaya lokal untuk mendukung membaca awal pada anak
}

\author{
Martha Christianti, Nur Hayati, Arumi Savitri Fatimaningrum \\ Pendidikan Anak Usia Dini, Fakultas Ilmu Pendidikan, Universitas Negeri Yogyakarta. \\ Jalan Colombo No. 1, Karangmalang, Yogyakarta, 55281, Indonesia \\ Email: marthachristianti@uny.ac.id,nurhayati@uny.ac.id,arumi@uny.ac.id
}

\begin{tabular}{ll}
\hline \hline ARTICLE INFO & ABSTRACT \\
\hline \hline Article history: & Penelitian ini bertujuan untuk menerapkan Language Experience Approach (LEA) \\
Received: $14-8-2019 ;$ & melalui cerita rakyat budaya lokal untuk mendukung membaca awal pada anak \\
Revised: $15-8-2019 ;$ & usia dini. Metode penelitian yang digunakan adalah eksperimen dengan desain \\
Accepted: $15-8-2019$ & ekperimen quasi eksperimen. Teknik pengumpulan data dengan observasi dalam \\
Keywords: & dentuk ceklist dan catatan lapangan. Hasil penelitian dianalisis dengan pendekatan \\
LEA; cerita; membaca awal; & LEA dengan beberapa tahap yaitu (1) tahap bercerita; (2) tahap anak menyampai- \\
anak; story; early reading; & kan pengetahuan melalui pertanyaan; (3) nak menuangka pengalaman melalui \\
children & gambar, huruf atau bentuk; (4) guru meminta anak untuk menceritakan hasil \\
& tulisannya secara lisan. Penelitian ini menunjukkan bahwa 80 persen anak di TPA \\
& $\begin{array}{l}\text { Dharma Yoga Santi mengalami kemajuan dalam membaca awal yang ditunjukkan } \\
\text { dalam kemampuan anak untuk menciptakan cerita dari pengalamannya mende- }\end{array}$ \\
& ngarkan cerita dalam bentuk tulisan dan kemampuan anak untuk menceritakan \\
& kembali cerita melalui hasil tulisannya dalam bentuk lisan atau tulisan. Anak anak \\
& mulai tumbuh rasa percaya diri untuk mengungkapkan ide melalui tulisan karena \\
& sering mendapatkan kesempatan dari guru untuk menuangkan idenya baik berupa \\
gambar maupun tulisan.
\end{tabular}

This study aims to apply the Language Experience Approach (LEA) through local folklore to enhance early reading in early childhood. The research employed the quasi experimental design. Data were collected by means of observation in the form of a checklist and field notes. The data were then analyzed by using the quantitative and qualitative descriptive approaches. The results show that this study apply the LEA approach with several stages, namely (1) the storytelling stage; (2) the stage where children conveys knowledge through questions; (3) the stage where children want to imagine experiences through images, letters or shapes; and (4) the stage where teacher asks children to verbally convey their writing results. This study also reveals that 80 percent of children in TPA Dharma Yoga Santi experienced progress in early reading as indicated in the children's ability to create stories in written from after they listen to certain stories and children's ability to retell stories in written and oral forms. Children begin to grow the confidence to express ideas through writing because they often get the opportunity from the teacher to express their ideas in the form of pictures and writing.

\section{PENDAHULUAN}

Indonesia memiliki indeks minat membaca 0,001 persen sesuai survei UNESCO (Go Bekasi. 2016; Kasiyun, 2015; Masengi, 2014). Hal ini berarti hanya ada 1 orang yang memiliki minat baca dari 1000 penduduk di Indonesia. Hasil survei ini menempatkan Indonesia pada urutan ke 60 dari 61 negara dengan literasi terrendah di bawah Thailand dan di atas Bostwana (Darnita, 2019; Handayani, 2018; Kompas, 2016). Menyikapi hal tersebut permendikbud no 23 tahun 2015 tentang penumbuhan budi pekerti mewajibkan anak untuk membaca 15 menit sebelum waktu pelajaran dimulai khususnya bagi siswa SD, SMP, dan SMA. Membaca merupakan kegiatan yang penting dilakukan untuk meningkatkan sumber daya manusia. Pembiasaan membaca sudah dimulai sejak usia dini. Hasil penelitian 
menunjukkan bahwa perolehan literasi anak diperoleh dari orang tuanya. Pengetahuan tentang alfabet adalah tahap awal yang harus dilalui ketika anak akan membaca. Bowman \& Treiman (2004) mengatakan bahwa anak-anak sudah membawa kemampuan alfabetnya sebelum masuk dalam sekolah. Dengan demikian pembiasaan yang dilakukan orang tua di rumah membantu anak untuk menghadapi keterampilan yang ada di sekolah. Beaty (2013) mengatakan pula bahwa akar literasi terbentuk dari rumah. Program literasi di sekolah sebaiknya mengikuti pola literasi anak di rumah. Untuk itu penting bagi guru untuk mengetahui pola literasi yang dilakukan anak di rumah agar program yang dirancang guru dapat sesuai dan memungkinkan untuk dilaksanakan. Jalongo (2000) menuliskan beberapa hasil penelitian terkait penyebab gangguan dan keterlambatan dalam membaca/bahasa pada anak-anak yaitu kepercayaan diri yang sedikit terhadap kemampuannya, sedikit kesempatan untuk membaca dari lingkungan rumah dan sekolah, sedikitnya motivasi untuk membaca atau tertarik untuk membaca, sedikitnya dukungan untuk membaca, sedikitnya atau tidak ada kesempatan untuk menggunakan keterampilan literasi untuk mengerjakan tugas yang bermakna bagi dirinya.

Terkait dengan hal tersebut Language Experience Approach (LEA) merupakan pendekatan yang membantu anak untuk memperluas perkembangan bahasa melalui pengalaman berbahasa yang mengikuti pola perkembangan masing-masing anak. LEA mengembangkan bahasa dalam bentuk kegiatan mendengar, berbicara, membaca, dan menulis. Keempat kegiatan tersebut difasilitasi dalam satu pendekatan pengalaman berbahasa yang menghasilkan makna pada anak. Mendengar dan berbicara menjadi kemampuan dasar yang harus dimiliki anak ketika LEA akan diterapkan dalam pembelajaran. Lewis, et.al (2011) dalam jurnalnya menuliskan bahwa anak-anak yang memiliki gangguan dalam kemampuan bicara maka akan mengalami gangguan pula dalam perolehan literasinya.

Tahapan kegiatan pembelajaran dengan LEA menurut Jalongo (2000) yaitu diawali dengan pengalaman konkrit, kemudian memproduksi cerita, dan diakhiri dengan menggunakan cerita yang disampaikan anak dan diterjemahkan oleh guru sebagai bahan bacaan. Pengalaman konkrit yang dapat disediakan oleh guru dapat berupa kegiatan karyawisata, memasak, berkebun, atau bahkan membaca buku bersama, atau menonton pertunjukan cerita boneka tangan atau boneka jari. Hasil dari pengalaman konkrit ini dapat menghasilkan cerita. Cerita yang dihasilkan anak dapat berupa tulisan atau gambar yang diciptakan sendiri oleh anak. LEA diakhiri dengan membacakan hasil gambarnya dan dibantu guru untuk diterjemahkan bahkan dituliskan ulang pada anak. LEA dirancang untuk menyadarkan anak tentang tulisan, mendukung interaksi sosial anak, mendukung anak untuk mempraktekkan bahasa tulis, dan membangun kebiasaan anak dengan bahasa lisan yang kemudian kearah membaca. Bagian penting dalam pendekatan pengalaman berbahasa (LEA) dan perannya dalam membaca awal pada anak menjadi penting untuk dilakukan sebagai pembiasaan dalam kegiatan pembelajaran. Cerita-cerita yang disajikan untuk anak-anak kebanyakan menggunakan cerita dengan setting cerita budaya barat seperti Cinderela, Putri Aurora, Gadis Berkerudung Merah, Tiga Babi dan Serigala, dan lain sebagainya. Anak belajar sesuatu dari budayanya. Melalui pembelajaran berbasis budaya, sejak usia dini seharusnya anakanak mendapatkan berbagai cerita yang sesuai dengan budaya tempat anak berada. Ketika cerita yang disampaikan guru tidak sesuai dengan budaya yang dialami anak, maka anak akan sulit memahami alur bahkan muatan cerita tersebut. Hal ini disebabkan karena perbedaan pengalaman yang dialami anak dengan alur serta setting cerita yang didengar oleh anak. LEA mengusahakan pengalaman berbahasa sesuai dengan pengalaman hidup anak termasuk didalamnya buku cerita yang dibaca oleh anak-anak. Hasil penelitian Christianti \& Cholimah (2012) tentang pengenalan karakter melalui cerita rakyat berbudaya lokal untuk anak usia dini menghasilkan 6 buku cerita rakyat dari Yogyakarta. Cerita-cerita tersebut diperoleh dari hasil kajian literatur terkait dengan dongeng yang dimiliki oleh rakyat Yogyakarta. Cerita-cerita tersebut dipilih dan disesuaikan dengan tahap perkembangan kognitif anak sehingga cerita yang cukup terkenal dari Yogyakarta tidak digunakan karena memiliki alur cerita yang sulit dipahami oleh anak-anak (tidak konkrit berkaitan dengan alam gaib dan lain sebagainya). Untuk itu enam judul cerita rakyat yang akan digunakan pula dalam penelitian ini berjudul Impian Kerlip Kunang, Legenda Rusa Bertanduk, Asal Mula Kali Gajah Wong, Asal Mula Desa Kembang, Kisah Kijang dan Lintah, dan Lurah Cokrojoyo. Cerita-cerita tersebut berisi konflik cerita yang sering dialami anak-anak dalam pergaulannya ada muatan karakter yang dapat dibentuk pada anak-anak melalui cerita tersebut.

Berdasarkan hasil pengamatan pada beberapa Taman Kanak-kanak di Kota Yogyakarta terkait dengan program literasi untuk mengenalkan membaca dan menulis awal, sudah sering dilakukan. Beberapa kegiatan yang dilakukan di sekolah tersebut yaitu mengajak anak untuk menebalkan huruf, 
membacakan cerita, menuliskan namanya, dan yang paling sering dilakukan adalah dengan mengisi Lembar Kerja Anak (LKA) yang berhubungan dengan kegiatan kebahasaan. Kegiatan-kegiatan yang dilakukan tersebut dianggap membosankan oleh anak karena guru mendorong anak-anak untuk melakukannya tanpa melihat bahwa pembelajaran tersebut bermakna atau tidak untuk anak. Beberapa anak bahkan tidak mengerti apa yang mereka tuliskan, hanya meniru tulisan yang ada di lingkungannya saja (LKA). Perilaku bosan yang ditampilkan oleh anak-anak seperti merebahkan kepala kemeja, tidak selesai mengerjakan, tertarik untuk mengerjakan kegiatan yang lain, menguap, perlu dimotivasi untuk mengerjakan tugasnya sampai selesai. Dalam LEA kebosanan ini mungkin saja terjadi karena perbedaan kemampuan yang diharapkan guru dengan yang dimiliki anak. LEA merupakan pendekatan yang mengajarkan kebahasaan pada anak secara bermakna berdasarkan pengalaman berbahasa masingmasing anak. Terkait dengan penggunaan buku cerita budaya lokal atau cerita rakyat yang digunakan di taman kanak-kanak, cerita- cerita tersebut jarang digunakan untuk bercerita karena keterbatasan buku bacaan yang dapat digunakan untuk bercerita. Guru-guru pun mengalami kesulitan dalam menemukan buku-buku tersebut. Pengetahuan guru terkait dengan cerita rakyat yang dapat digunakan guru sebagai sumber belajar juga minim.

Permasalahan ini yang kemudian mendukung peneliti untuk melakukan penelitian terapan untuk mencoba pendekatan baru yang belum pernah dilakukan sebelumnya di Taman Kanak-kanak menggunakan LEA dengan harapan motivasi anak untuk membaca, menulis ditahap awal kehidupan anak menjadi dorongan dan semangat bagi anak untuk menumbuhkan minat terhadap literasi sejak dini.

\section{METODE}

Penelitian ini menggunakan metode eksperimen dengan desain pretest dan posttest (pretestpostest one-group desain). Adapun bagan alir dalam penelitian ini dapat dilihat pada Gambar 1.

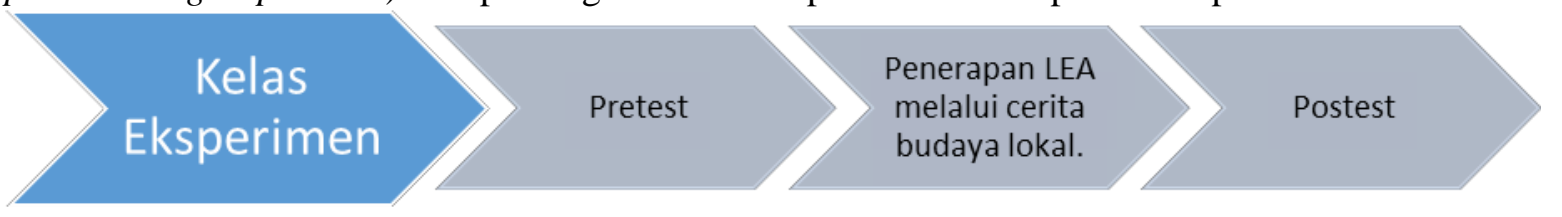

Gambar 1. Alur Penelitian

Subjek penelitian adalah anak-anak usia 3 hingga 6 tahun dan guru di TPA Darma Yoga Santi berjumlah 7 orang anak. Lokasi penelitian di Jalan Colombo No.1 Karang Malang Catur Tunggal, Depok Sleman, Yogyakarta. Penelitian dilakukan pada bulan Agustus dan September 2017. Data dikumpulkan dengan teknik observasi dalam bentuk ceklis dan perekaman terhadap membaca awal anak. Hasil pengamatan tersebut kemudian diolah dalam bentuk penilaian secara kuantitatif terhadap kemampuan anak. Meskipun demikian segala hal yang terkait dengan penerapan LEA dalam mendukung membaca awal pada anak dicatat dalam bentuk catatan lapangan.

Adapun kisi-kisi tindakan yang harus dilakukan guru adalah melakukan persiapan sebelum bercerita, menetapkan kosakata yang akan digunakan dalam cerita (menjadi target untuk diucapkan anak ketika proses menceritakan kembali), menyiapkan media yang dibutuhkan, memahami bacaan secara mendalam, melaksanakan kegiatan bercerita sebagai tahap awal dalam pendekatan language experience, memberi kesempatan pada anak untuk membuat cerita, meminta anak untuk menceritakan ceritanya dan dibantu guru menerjemahkan cerita tersebut dalam bentuk tulisan. Tabel 1, merupakan kisi-kisi instrumen literasi awal.

Tabel 1. Kisi-kisi Instrumen Literasi Awal

\begin{tabular}{llc}
\hline Variabel & Indikator & No \\
\hline Literasi Awal & anak dapat mendengarkan cerita, & 1 \\
& anak dapat merespon cerita dalam bentuk komentar atau pertanyaan, & 2 \\
& anak mampu menciptakan cerita sesuai dengan pengalamannya dalam bentuk tulisan & 3 \\
& berupa gambar/bentuk/huruf, \\
& anak mampu menceritakan kembali hasil tulisannya. & 4 \\
\hline
\end{tabular}

Kesahihan instrumen diuji dengan uji validitas konstruk dengan ekspert judment dan uji lapangan terbatas untuk diujicoba pada anak. Uji reliabilitas instrumen dengan metode retest yaitu untuk menguji realibilitas suatu test dengan cara melakukan pengujian dua kali untuk test yang sama pada orang yang 
Martha Christianti, Nur Hayati, Arumi Savitri Fatimaningrum

sama (Kountur, 2018). Hasil penelitian dianalisis dengan uji T dengan kreateria jika $t$-tabel $>$ t-hitung maka hipotesis alternatif ditolak. Namun jika t-tabel < thitung maka hipotesis nol ditolak. Hasil uji validitas dan reliabilitas instrumen seperti pada Tabel 2 .

Tabel 2. Uji Validitas Instrumen Literasi Awal

\begin{tabular}{|c|c|c|c|c|c|c|}
\hline & & total & indikator_0 1 & indikator_0 2 & indikator_0 3 & indikator_0 4 \\
\hline \multirow[t]{3}{*}{ total } & Pearson Correlation & 1 & $.659^{* *}$ & $.733^{* *}$ & $.770^{* *}$ & $.838^{* *}$ \\
\hline & Sig. (2-tailed) & & .005 & .001 & .000 & .000 \\
\hline & $\mathrm{N}$ & 16 & 16 & 16 & 16 & 16 \\
\hline \multirow[t]{3}{*}{ indikator_0 1} & Pearson Correlation & $.659^{* *}$ & 1 & $.561^{*}$ & .218 & .303 \\
\hline & Sig. (2-tailed) & .005 & & .024 & .417 & .255 \\
\hline & $\mathrm{N}$ & 16 & 16 & 16 & 16 & 16 \\
\hline \multirow[t]{3}{*}{ indikator_0 2} & Pearson Correlation & $.733^{* *}$ & $.561^{*}$ & 1 & .234 & .367 \\
\hline & Sig. (2-tailed) & .001 & .024 & & .384 & .162 \\
\hline & $\mathrm{N}$ & 16 & 16 & 16 & 16 & 16 \\
\hline \multirow[t]{3}{*}{ indikator_0 3} & Pearson Correlation & $.770^{* *}$ & .218 & .234 & 1 & $.832^{* *}$ \\
\hline & Sig. (2-tailed) & .000 & .417 & .384 & & .000 \\
\hline & $\mathrm{N}$ & 16 & 16 & 16 & 16 & 16 \\
\hline \multirow[t]{2}{*}{ indikator_0 4} & Pearson Correlation & $.838^{* *}$ & .303 & .367 & $.832^{* *}$ & 1 \\
\hline & Sig. (2-tailed) & .000 & .255 & .162 & .000 & 16 \\
\hline & $\begin{array}{l}N \\
\text { is sionific }\end{array}$ & $\begin{array}{l}16 \\
\text { level }\end{array}$ & $\begin{array}{l}16 \\
\text {-tailed). }\end{array}$ & 16 & 16 & \\
\hline
\end{tabular}

Jika $r$ hitung $>r$ tabel berarti valid. Jika $r$ hitung $<\mathrm{r}$ tabel berarti tidak valid. Digunakan tingkat kepercayaan 95\%. Jumlah responden $=16$ dengan $\mathrm{R}$ tabel $(95 \% ; 16)=0,497$. Semua indikator valid. Berikut ini data hasil perhitungan $\mathrm{R}$ hitung dan $\mathrm{R}$ tabel.

Tabel 3. Hasil Validitas Instrumen Literasi Awal

\begin{tabular}{llll}
\hline Indikator & R hitung & R tabel & Keterangan \\
\hline 1 & 0,659 & 0,497 & Valid \\
2 & 0,733 & 0,497 & Valid \\
3 & 0,770 & 0,497 & Valid \\
4 & 0,838 & 0,497 & Valid \\
\hline
\end{tabular}

Tabel 4. Uji Reliabilitas Instrumen

\begin{tabular}{llll}
\hline & & $\mathrm{N}$ & $\%$ \\
\hline Valid Cases $^{\mathrm{a}}$ & 16 & 100.0 \\
Excluded $^{\mathrm{a}}$ & & 0 & .0 \\
& Total & 16 & 100.0
\end{tabular}

Reliability Statistics

Cronbach's Alpha .737
$\mathrm{N}$ of Items

4

Jika Cronbach's Alpha > 0,6 berarti reliabel. Jika Cronbach's Alpha < 0,6 berarti tidak reliabel. Cronbach's Alpha 0,737 > 0,6 berarti reliabel. Berdasarkan pengujian tersebut maka instrumen literasi awal valid dan reliabel untuk digunakan dalam penelitian.

\section{HASIL DAN PEMBAHASAN}

Penelitian tahap awal dilakukan mendiskusikan dan melatih guru-guru dalam pendekatan LEA. Pendekatan LEA dengan langkah-langkah pembelajaran yaitu pertama, kegiatan bercerita. Pada tahap ini, anak-anak dapat mendengarkan cerita guru tentang sebuah topik tertentu. Guru kemudian menggambarkan cerita di papan tulis sambil menuliskan kata-kata yang harus dikenal anak. Kemudian pada langkah kedua, guru meminta anak untuk menyampaikan pengetahuan yang dimilikinya dalam bentuk pertanyaan atau pernyataan. Langkah ketiga, guru meminta anak menuangkan pengalaman mendengarkan cerita dalam bentuk tulis berupa gambar/bentuk/huruf, sesuai keinginannya. Langkah 
keempat, guru meminta anak untuk menceritakan hasil tulisannya secara lisan kepada guru. Tahap kedua dalam penelitian yaitu membuat rancangan belajar untuk anak dalam bentuk RPPH. Guru menentukan KD dan membuat skenario pembelajaran untuk mengamati perkembangan anak. Kemudian ditetapkan beberapa tema yang sesuai dengan pengalaman anak yaitu vaksin rubela, cerita rakyat, dan diri sendiri.

Penelitian pada hari pertama dilakukan di kelas Lir-ilir usia 3-4 tahun. Tema yang digunakan adalah tentang Vaksin Rubela. Tema ini diangkat karena hari sebelumnya anak-anak mengikuti kegiatan vaksin bersama-sama di sekolah. Pengalaman nyata yang dialami anak dapat diangkat sebagai tema menarik untuk dibicarakan dan dibahas lebih lanjut dalam pembelajaran. Langkah yang dilakukan guru setelah menetapkan tema adalah memilih KD dan menyusun bahan ajar.

Guru menyusun bahan ajar dengan menyiapkan video anak disuntik vaksin, gambar, serta peralatan bermain dokter- dokteran. Pelaksanaan LEA dilakukan dengan mengajak anak menonton video, dan mendengarkan cerita tentang dokter dan pasien. Guru menunjukkan gambar dokter dan perlengkapan dokter. Langkah selanjutnya guru mempersilahkan anak untuk bermain peran menjadi dokter dan pasien. Langkah ketiga, guru meminta anak untuk menuliskan sesuatu pada kertas. Anak terlihat kesulitan karena ini pertama kalinya anak mendapatkan kegiatan bermain bersama kertas dan krayon. Anak sering menunjukkan rasa tidak percaya diri dengan mengatakan, "mbak.. aku diajari". Pada tahap ini anak membutuhkan penguatan terhadap hasil karyanya, "lihat mbak, bagus kan?". Tahap menceritakan kembali hasil karyanya dilakukan dengan memanggil anak-anak satu persatu kedepan kelas. Namun beberapa anak masih belum mau menceritakan hasil karyanya. Berikut ini foto tahapan LEA dalam pembelajaran untuk meningkatkan literasi awal pada anak.
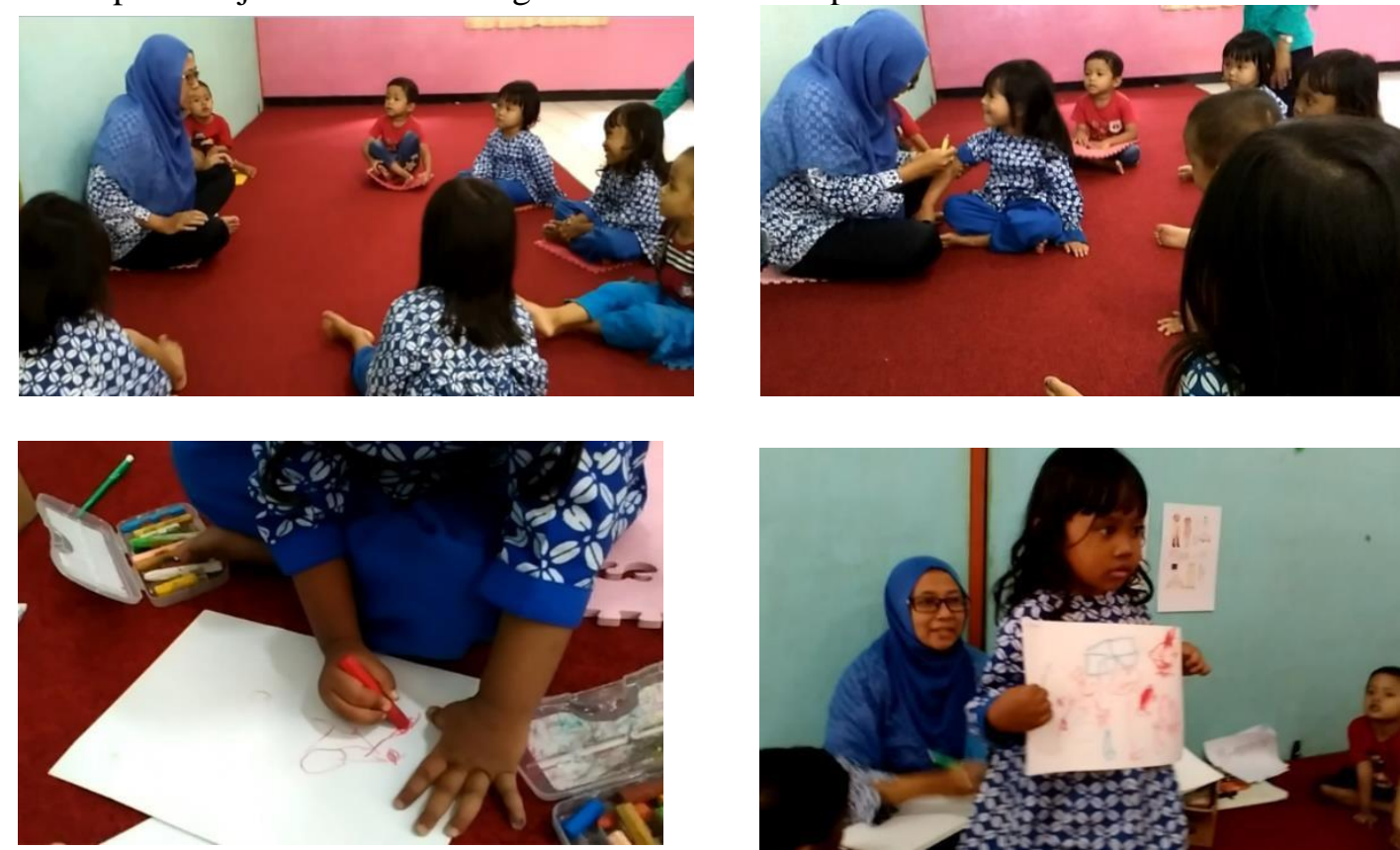

Penelitian hari kedua dilakukan masih di kelas Lir-ilir. Tema yang digunakan adalah cerita rakyat. Judul cerita yang diambil adalah Kali Gajah Wong. Kegiatan awal dilakukan dengan menunjukkan beberapa gambar gajah di kebun binatang dan ketika acara Grebekan di Kraton. Tahap pertama pendekatan LEA dilakukan dengan menceritakan kisah tentang asal mula kali gajah wong. Anak diminta mengulangi ucapan beberapa kata-kata baru seperti "bisul, ki, Pejok, kali, kakek". Guru menggambar dan menuliskan beberapa kata yang terdapat pada cerita kali gajah wong. Langkah selanjutnya, guru membagikan kertas dan krayon kepada anak untuk menuliskan apa yang sudah didengar dari cerita. Sebagian anak mengalami kesulitan ketika diminta untuk menuliskan kembali cerita yang sudah didengar. Beberapa anak belum belum menunjukkan rasa percaya diri dengan mengatakan "aku mau digambarin". Pada tahap ini juga, anak membutuhkan motivasi agar mau menuliskan cerita yang sudah didengar. Tahap terakhir yaitu anak menceritakan hasil karyanya. Anak diberikan kesempatan satu persatu untuk bercerita tentang hasil karya yang sudah dibuat. Namun, sebagian anak belum mau menceritakan hasil karyanya tersebut. Berikut ini pelaksanaan LEA dihari kedua. 

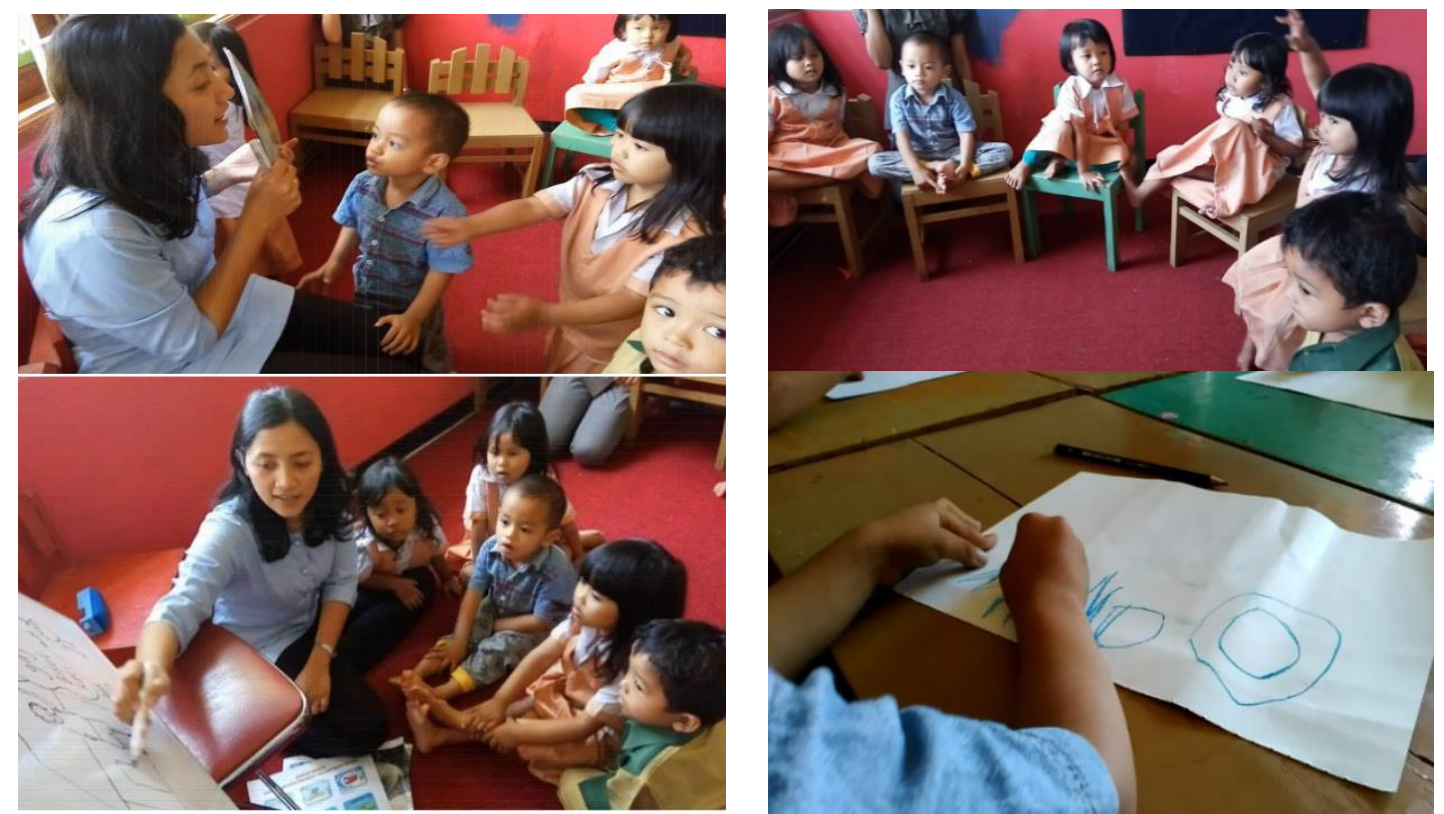

Penelitian hari ketiga tetap dilakukan di kelas Lir-ilir. Tema yang digunakan masih tentang cerita rakyat. Judul cerita yang diambil pada pertemuan ketiga yaitu Impian Kerlip Kunang. Kegiatan awal dilakukan dengan guru bertanya "anak-anak pernah tau gak, apa itu kunang-kunang?" dan sedikit memberikan informasi tentang kunang-kunang, selanjutnya guru mulai bercerita tentang Impian Kerlip Kunang. Tahap pertama pendekatan LEA dilaksanakan dengan menceritakan tentang impian kerlip kunang yang ingin terbang sampai ke bintang. Setelah bercerita tentang Impian Kerlip Kunang, selanjutnya guru menggambar dan menuliskan beberapa bagian yang ada pada cerita seperti "ayah, ibu, kunang, dan bintang". Tahap selanjutnya, guru membagikan kertas dan krayon pada masing-masing anak. Anak diberikan kesempatan untuk menulis dan menggambarkan tentang cerita Impian Kerlip Kunang. Pada saat mulai menggambar dan menuliskan dalam selembar kertas yang diberikan oleh guru, semua anak sudah mau mengerjakan secara mandiri. Terlihat beberapa anak membutuhkan penguatan dengan berkata "bu guru gini bu guru?" selanjutnya guru memberikan penguatan "iya, bagus seperti itu". Tahap terakhir pendekatan LEA yaitu anak menceritkan hasil karya. Anak diberikan kesempatan satu persatu untuk meceritakan hasil karyanya. Anak yang

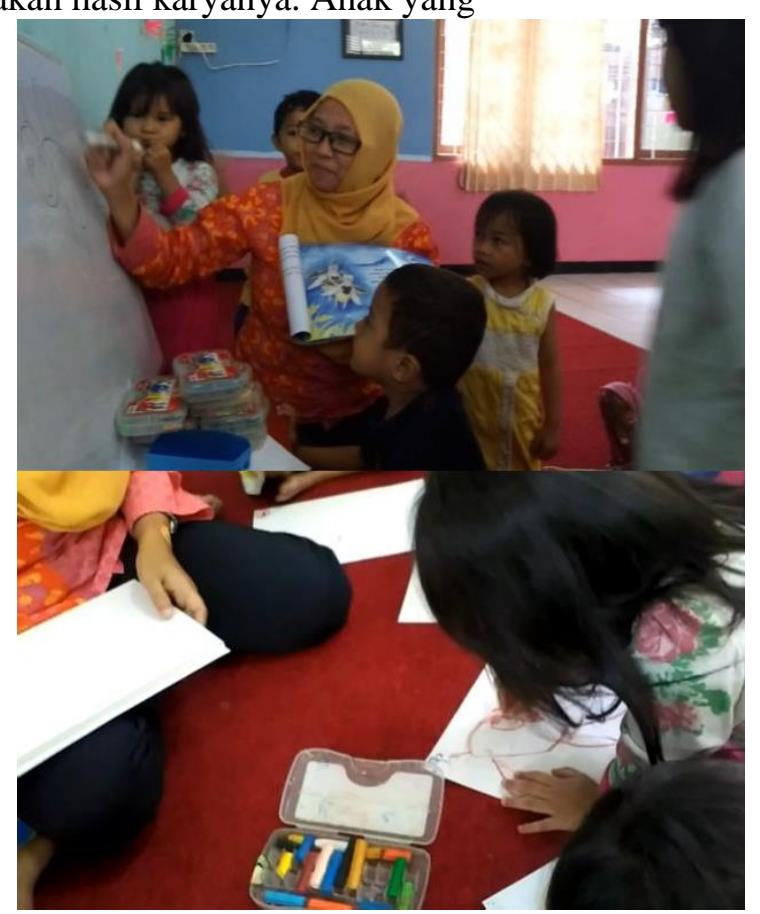

Pelaksanaan penelitian hari keempat dilakukan di kelas Lir-ilir. Tema yang digunakan tentang cerita rakyat. Judul yang diambil pada pertemuan keempat yaitu Rusa Bertanduk. Sebelum memulai 
bercerita tentang Rusa Bertanduk, guru terlbih dahulu memberikan tebak-tebakan kepada anak menggunakan nyanyian "siapa tau ini namanya hewan apa? ayo ayo ayo ditebak, ada tanduknya dua, makannya rumput". Anak dimotivasi untuk menjawab tebakan yang diberikan guru. Setelah anak menjawab tebak-tebakan, guru selanjutnya mulai bercerita tentang Rusa Bertanduk. Beberapa anak fokus mendengarkan cerita yang disampaikan guru, namun masih terdapat anak-anak yang kurang fokus mendengarkan cerita. Guru mencoba meminta perhatian anak dengan memanggil nama masingmasing anak dan mau maju mnceritakan hasil karyanya diberikan penghargaan berupa stiker. Namun ada anak yang maju tetapi belum percaya diri untuk menceritakan hasil karyanya. Berikut ini foto penerapan LEA di hari ketiga.

memberikan tanda bi

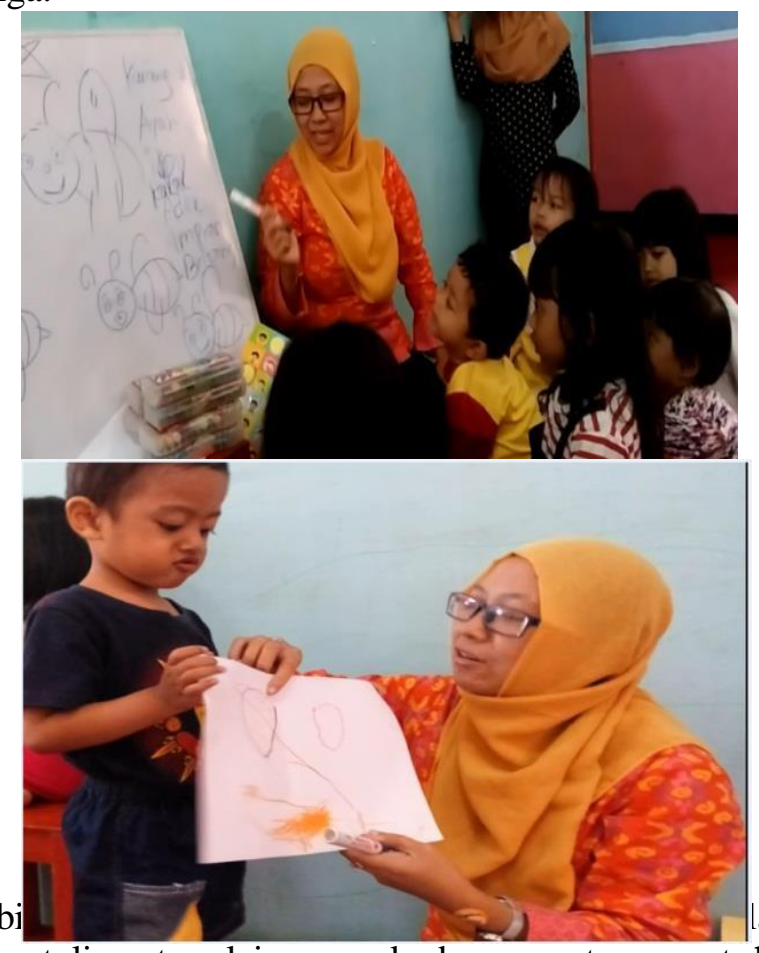

lanjutnya, guru menuliskan beberapa kata-kata di papan tulis antara lain, rusa, kuda, rumput, monyet, harimau, dan tanduk. Guru menyebutkan kata yang ditulis, kemudian meminta anak untuk mengulang kata yang tertulis di papan tulis. Tahap berikutnya adalah membuat hasil karya dengan menuliskan kembali cerita yang sudah di dengar. Guru membagikan selembar kertas dan crayon pada masing-masing anak. Semua anak mengerjakan secara mandiri dengan terus diberikan penguatan oleh guru. Tahap terakhir, anak maju ke depan untuk menceritakan hasil karyanya di depan teman-temannya. Terlihat satu anak yang belum mau menceritakan hasil karyanya. Berikut ini penerapan LEA di hari keempat. 


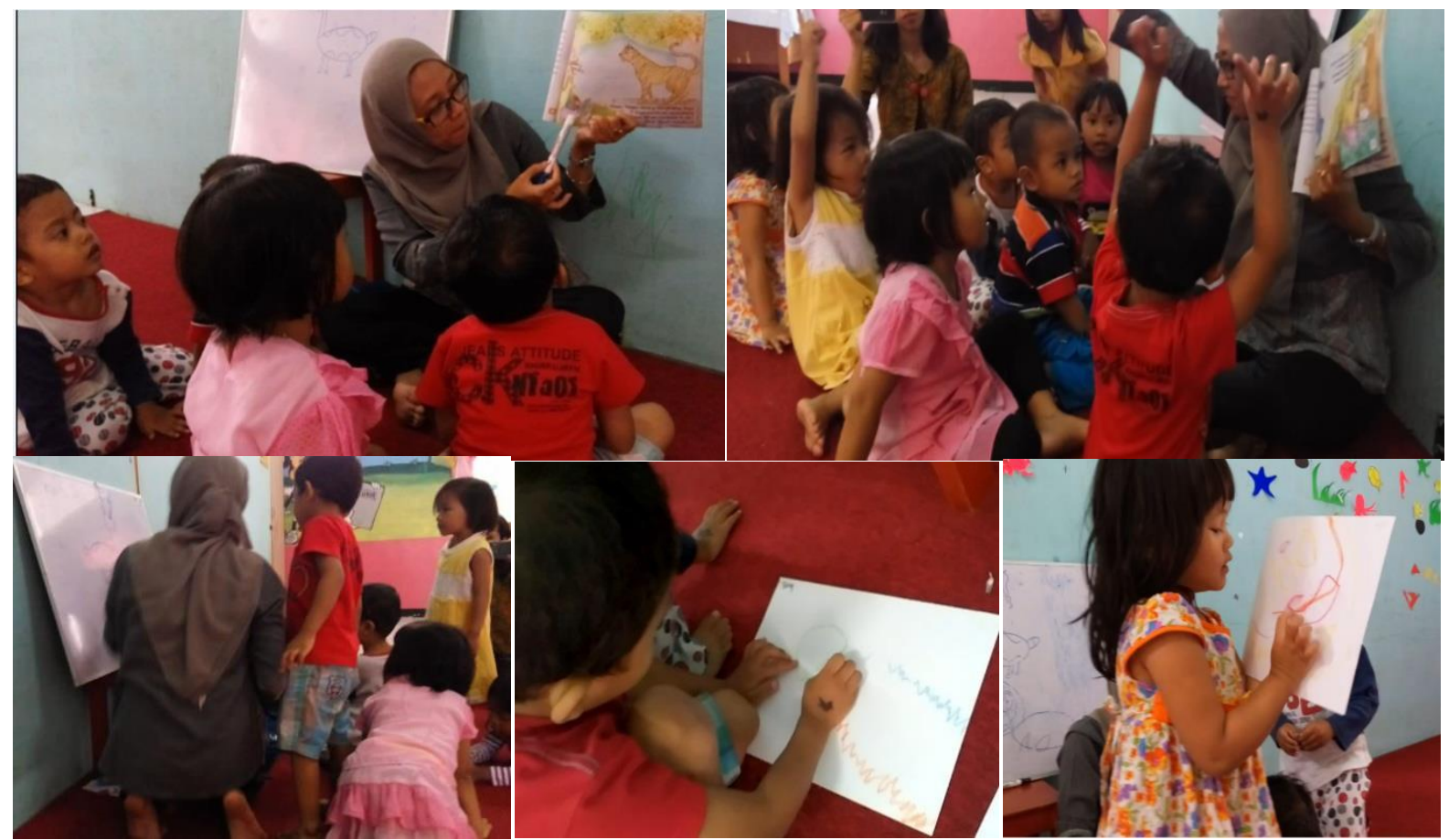

Pelaksanaan penelitian hari kelima dilakukan di kelas Lir-ilir. Judul cerita yang digunakan pada hari kelima adalah Aku Bisa Jadi Anak Rapi. Sebelum memulai cerita anak diajak untuk tepuk rapi. Guru memberikan pengertian kepada anak untuk selalu menjaga kerapian. Anak diminta agar selalu mengembalikan mainan ke tempat semula setelah selesai bermain. Guru mulai bercerita tentang Aku Bisa jadi Anak Rapi, kemudian menggambarkan dan menuliskan benda-benda yang terdapat dalam cerita di papan tulis. Anak diminta untuk mengulang kembali kata yang dituliskan oleh guru dipapan tulis. Tahap selanjutnya yaitu anak menggambarkan dan menuliskan beberapa benda yang sudah diceritakan. Anak lebih banyak menceritakan hasil karyanya ketika sedang menggambar. Semua anak dapat mengerjakan dan menggambar secara mandiri dengan terus diberikan motivasi oleh guru. Tahap selanjutnya yaitu anak menceritakan hasil karya yang sudah dibuat. Anak diberikan kesempatan satu persatu untuk menceritakan hasil karyanya. Anak dapat menceritakan hasil karyanya meskipun ada beberapa yang bercerita menggunakan bahasa tubuh. Berikut ini penerapan LEA di hari kelima.

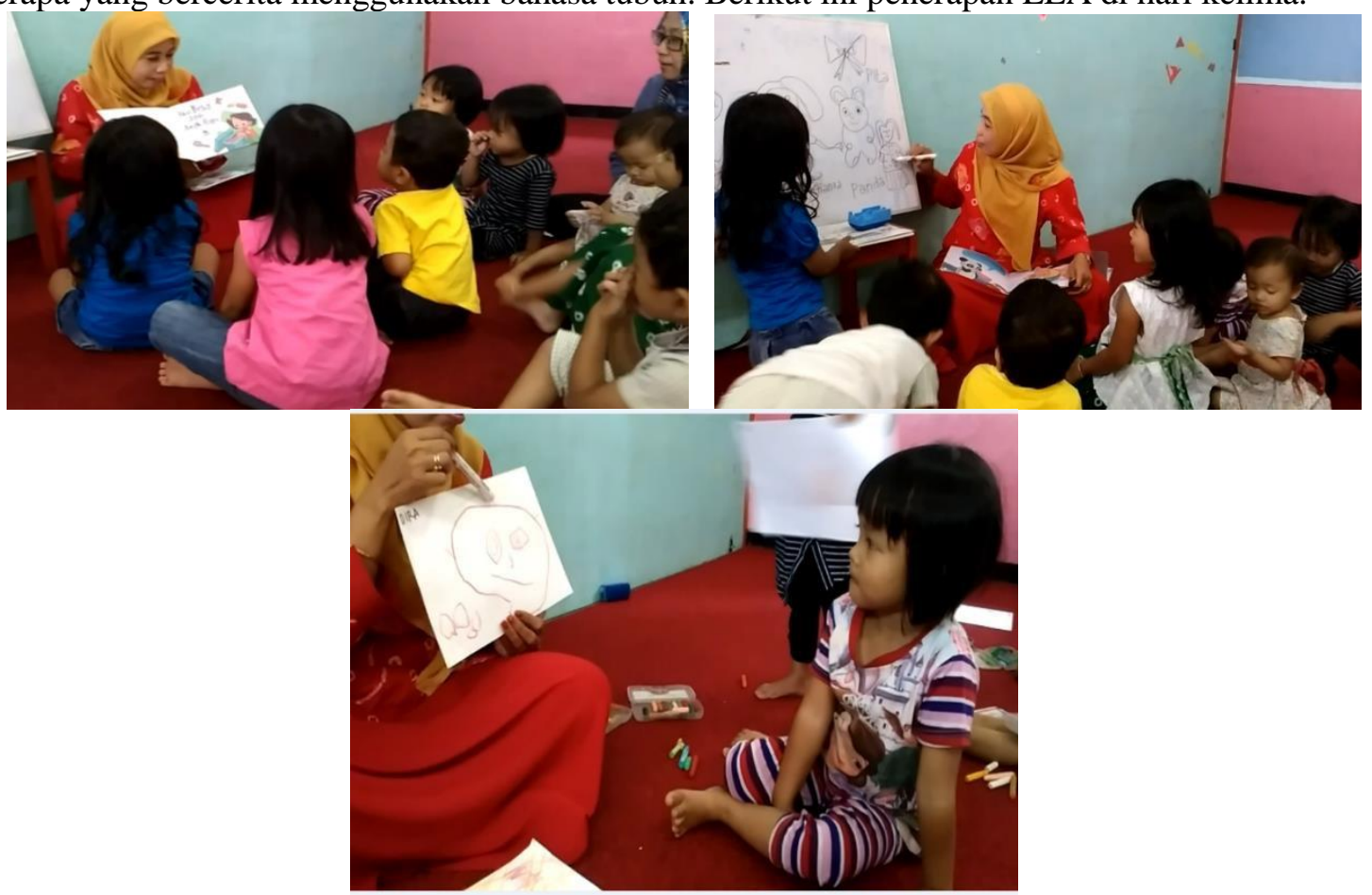

Pelaksanaan penelitian hari keenam masih dilaksanakan di kelas Lir-ilir. Tema cerita yang 
diambil adalah keluarga. Kegiatan awal dilakukan dengan bernyanyi "Satu-satu Aku Sayang Ibu". Guru meminta anak untuk menyebutkan setiap anggota keluarganya. Guru menunjukkan media papan kayu gambar anggota keluarga kemudian anak diminta untuk menyebutkannya. Tahap pertama penerapan LEA yaitu guru bercerita tentang budi berangkat ke sekolah. Guru menempelkan papan kayu gambar anggota keluarga seperti ayah, ibu, anak, kakek,

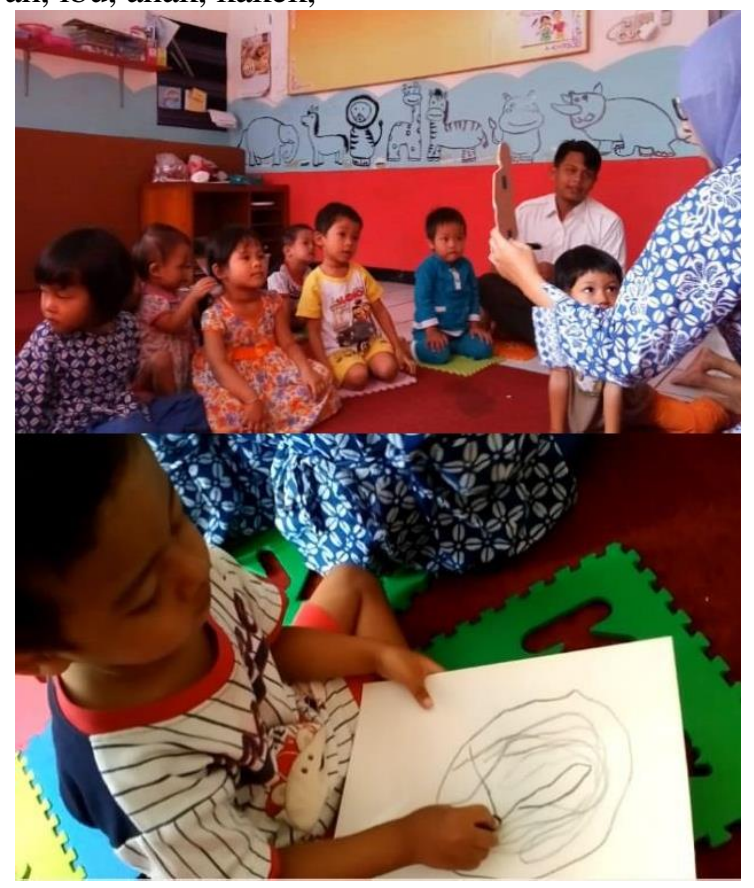

Pelaksanaan penelitian hari ketujuh dilaksanakan dikelas Lir-ilir. Tema cerita yang diambil adalah binatang dengan judul cerita Ayam dan Kupu-kupu.

dan nenek di depan kelas. Anak diminta satu persatu maju ke depan menyebutkan setiap anggota keluarga dan mengulanginya. Langkah selanjutnya adalah guru membagikan selembar kertas dan crayon yang sudah disiapkan kepada masing-masing anak. Semua anak dapat mengerjakan secara mandiri dengan diberikan penguatan oleh guru. Tahap selanjutnya adalah menceritakan kembali hasil karya yang sudah dibuat anak. Anak menceritakan hasil karyanya sesuai dengan pengalaman masingmasing. Berikut ini penerapan LEA di hari ke enam.

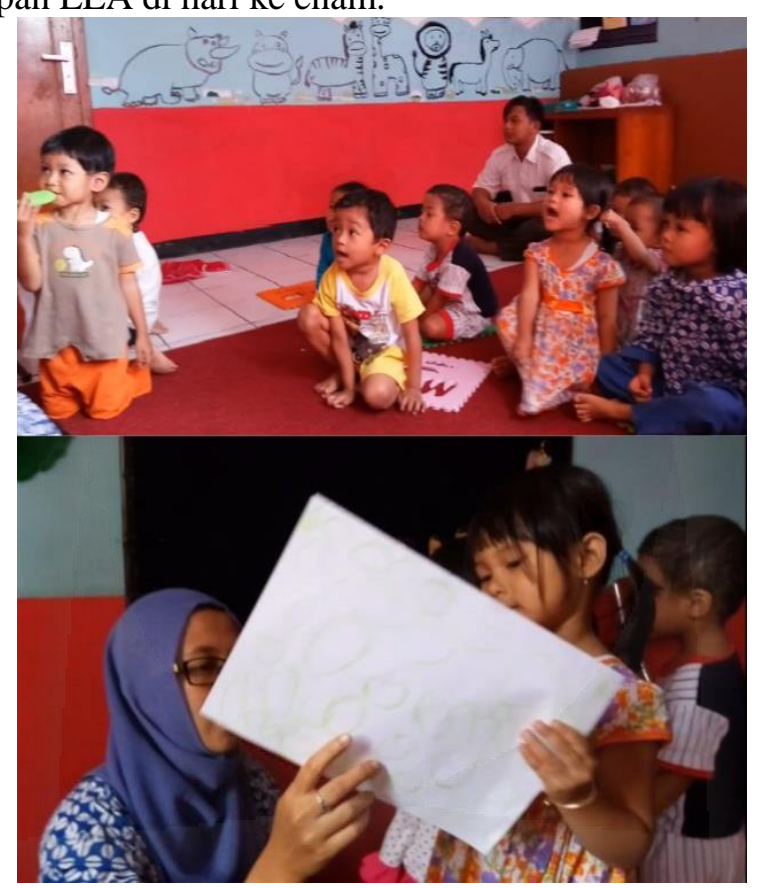

Pengkondisian dengan kegiatan awal dilaksanakan dengan aktifitas fisik yaitu lompat di lingkaran yang berwarna-warni sekaligus perkenalan warna hijau, kuning, biru, dan merah. Setiap anak 
diberikan kesempatan untuk melaksanakan aktifitas fisik. Setelah itu, guru mengajak anak untuk duduk melingkar dan memperkenalkan cerita yang akan disampaikan. Guru menunjukkan buku cerita bergambar tentang Ayam dan Kupu- kupu. Anak diminta menceritakan pengalamannya terkait dengan ayam dan kupu-kupu. Tahap pertama penerapan LEA yaitu guru bercerita tentang ayam dan kupu-kupu. Guru menyampaikan kalimat yang sama berulang kemudian guru mengulang pertanyaan yang sama kepada anak terkait kalimat yang disampaikan. Kalimat yang disampaikan guru misalnya "pada suatu hari seekor ayam hidup di hutan..." kemudian guru bertanya kepada anak "ayamnya hidup dimana?". Guru menyampaikan cerita

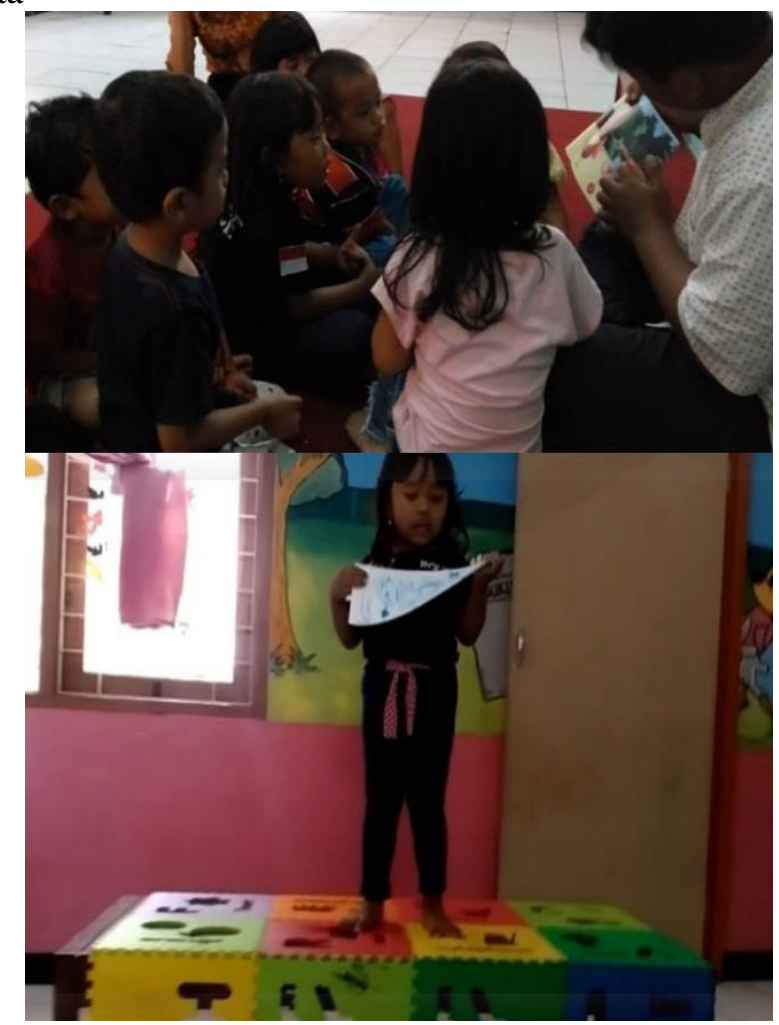

Pelaksanaan penelitian hari kedelapan dilakukan di kelas Lir-ilir. Tema cerita yang digunakan adalah cerita rakyat. Judul cerita yang diambil yaitu Kembang Bulan. Kegiatan awal dimulai dengan aktifitas fisik di dalam kelas. Anak meletakkan balok warna sesuai dengan dengan beberapa kata yang diulang secara terus menerus. Guru menggambar dan menuliskan beberapa kata benda yang terdapat dalam cerita yaitu ayam, kupu-kupu, sakit, anak ayam, kandang, dan bersahabat. Tahap selanjutnya yaitu anak menuliskan kembali dalam buku gambar terkait cerita yang sudah disampaikan oleh guru. Anak dapat mengerjakan secara mandiri sesuai dengan pengalaman yang sudah didapatkannya. Tahap terakhir adalah anak menceritakan kembali hasil karya yang sudah dibuat di depan teman-temannya. Anak termotivasi menceritakan hasil karyanya di depan kelas dikarenakan dibuat panggung mini untuk bercerita. Hal ini terlihat dari semua anak yang antusias untuk bercerita di panggung mini. Berikut ini penerapan LEA di hari ketujuh. 


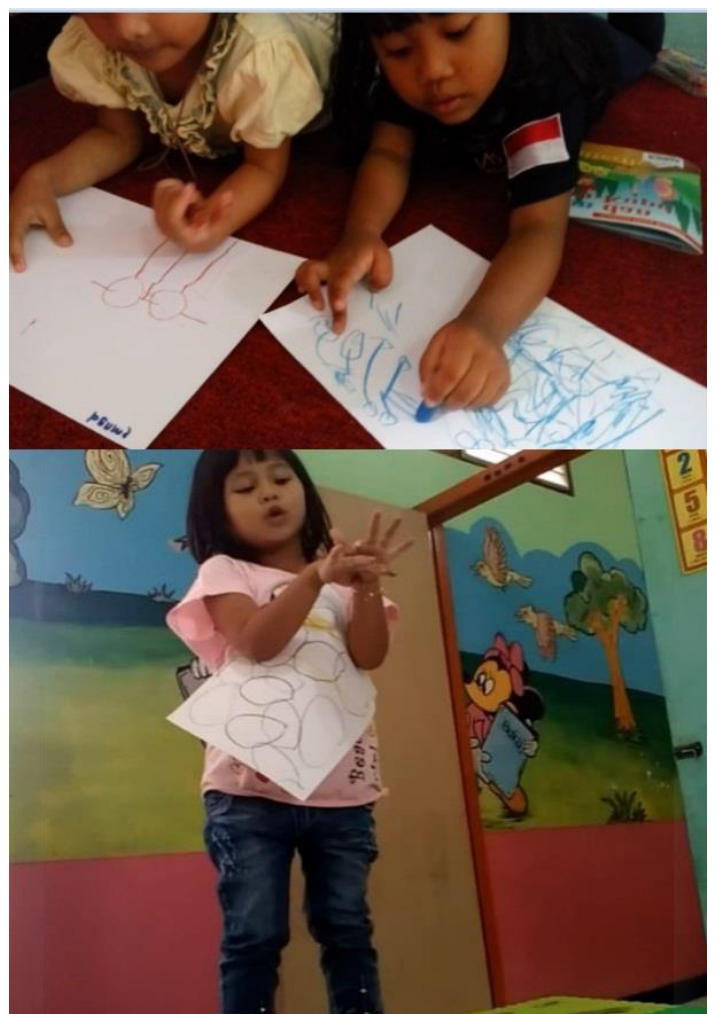

warna lingkaran yang sama. Tahap pertama penerapan LEA yaitu guru menyampaikan cerita yang berjudul Kembang Bulan menggunakan buku cerita rakyat bergambar. Guru menyampaikan cerita dengan ekspresif sehingga menarik perhatian anak unuk mendengarkan cerita.

Tahap selanjutnya, guru menggambarkan di papan tulis beberapa kata yang ditemukan dalam cerita seperti Jaka Prayoga, pohon pisang, Kembang Bulan, dan Jaka Apus. Guru mengulang kembali kata yang dituliskan di papan tulis dan meminta anak untuk menirukan. Tahap berikutnya yaitu anak diminta untuk menuliskan cerita yang didengar melalui gambar atau tulisan. Anak dapat menulis

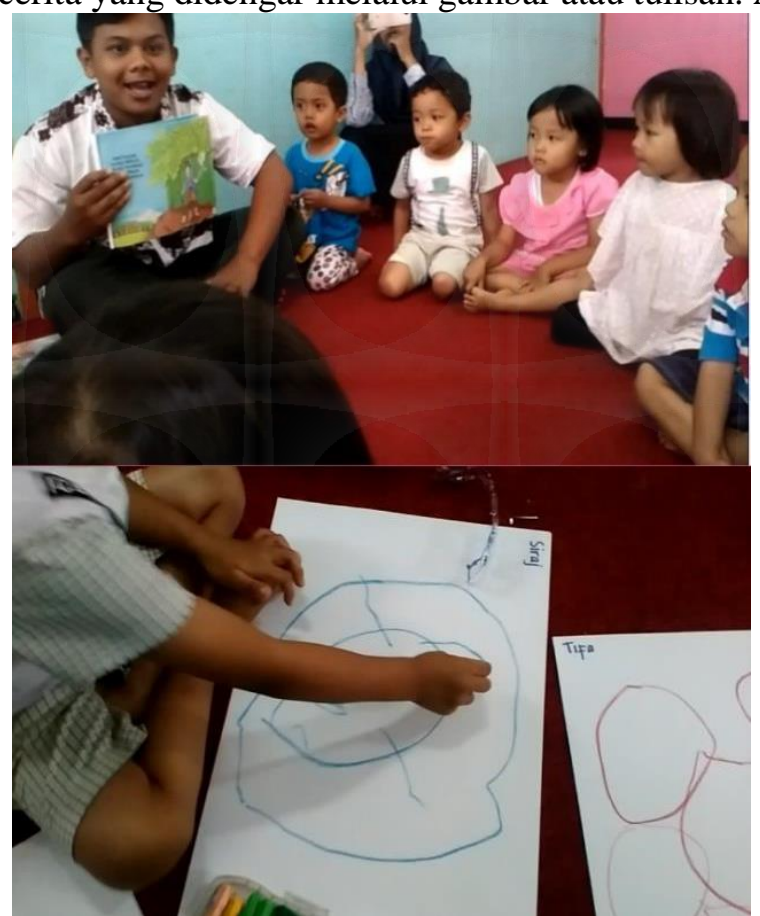

Pelaksanaan pembelajaran dengan pendekatan pengalaman berbahasa (LEA) dianalisis melalui uji T. Berikut ini data secara mandiri sesuai dengan cerita yang sudah didengar. Tahap akhir dari penerapan LEA adalah menceritakan kembali hasil karya yang sudah dibuat anak. Beberapa anak dapat menceritakan hasil karyanya tanpa ditanya oleh guru terlebih dahulu. Namun, terdapat satu anak yang 
Martha Christianti, Nur Hayati, Arumi Savitri Fatimaningrum

belum menceritakan hasil karyanya. Berikut ini penerapan LEA di hari kedelapan.

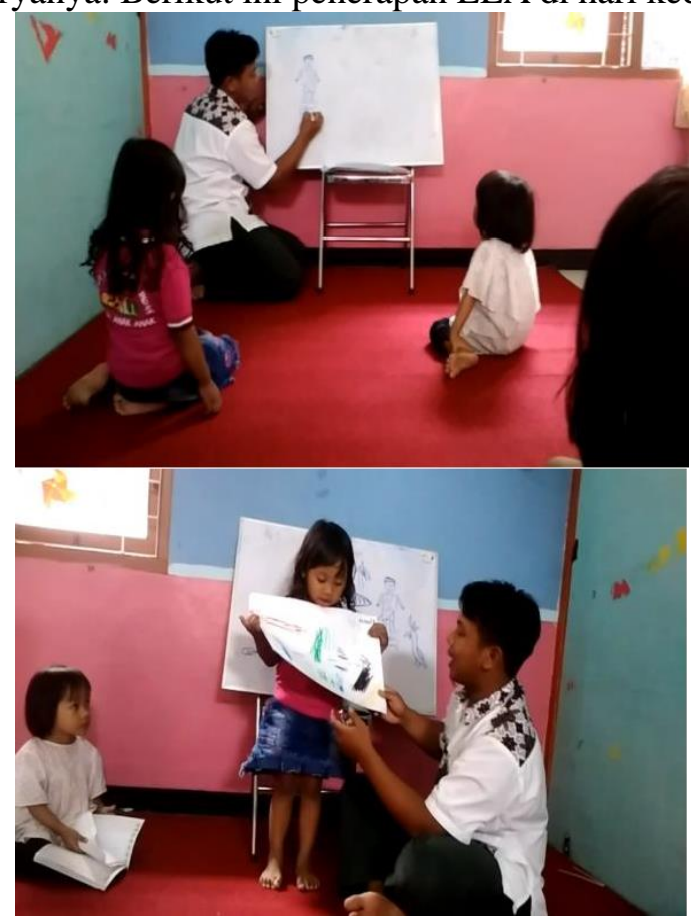

hasil peningkatan literasi awal setelah menggunakan LEA.

Tabel 5. Data Hasil Pretest dan Posttest Literasi Awal Anak

\begin{tabular}{ccc}
\hline No. Responden & Pretest & Posttest \\
\hline 1. & 3 & 4 \\
2. & 1 & 4 \\
3. & 1 & 4 \\
4. & 4 & 4 \\
5 & 2 & 4 \\
6 & 1 & 4 \\
7 & 2 & 4 \\
\hline
\end{tabular}

Berikut ini analisis uji $\mathrm{T}$ terkait dengan data pretest dan posttest.

Tabel 6. Uji T Hasil Penelitian

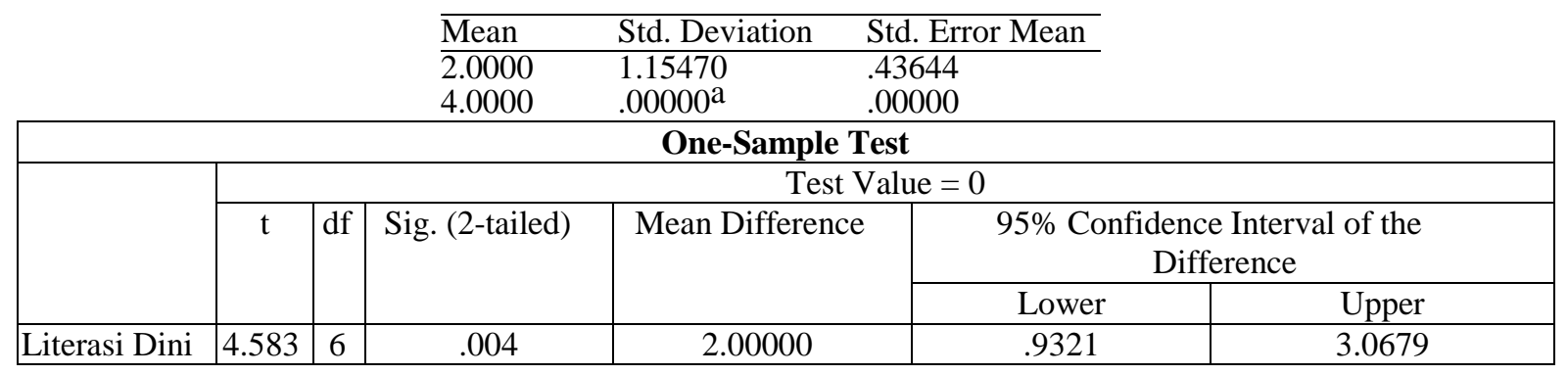

Berdasarkan perhitungan tersebut $\mathrm{t}$-hitung $=4,583>$ ttabel $=1,895$. Hal ini berarti hipotesis alternatif diterima. Hasil penelitian menunjukkan bahwa ada perbedaan hasil antara pretest dan posttest. Penelitian ini pula dimaknai bahwa LEA dapat mempengaruhi literasi awal anak secara signifikan. Berdasarkan hasil penelitian, diperoleh data perkembangan literasi awal anak yang semakin meningkat. Berikut ini peningkatan literasi awal pada anak di TPA Darma Yoga Santi dapat dilihat pada Gambar 2. 


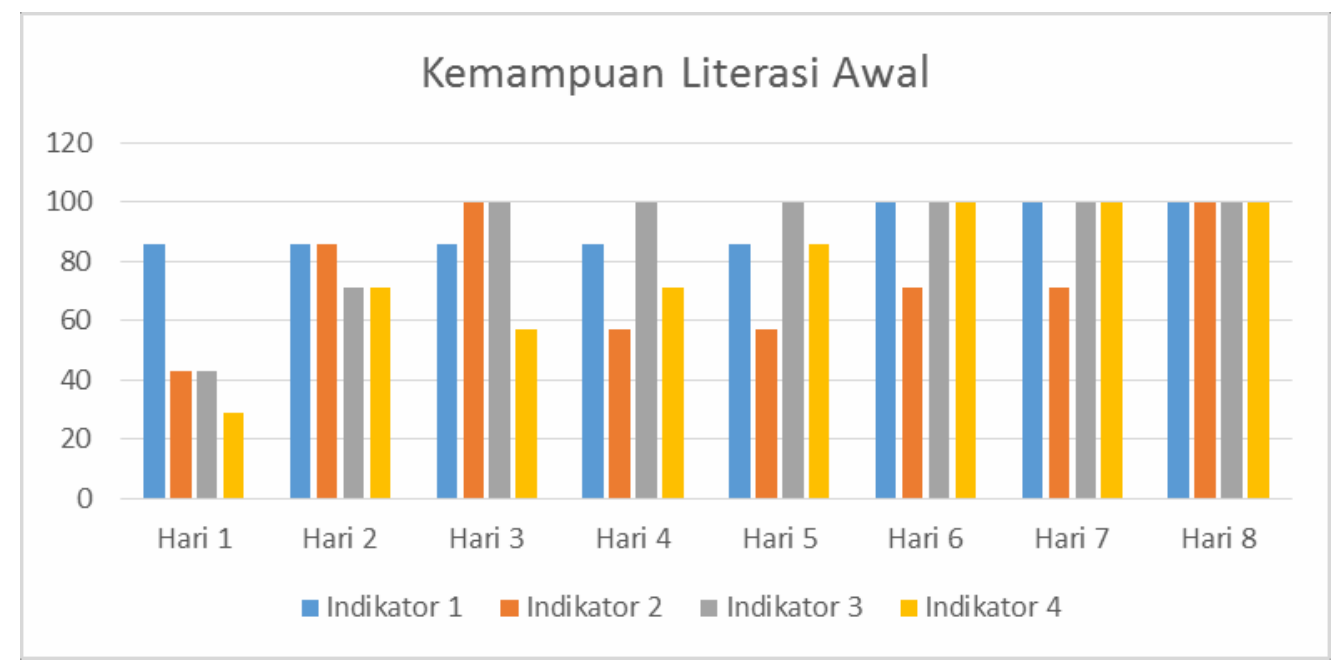

Gambar 2. Hasil Kemampuan Literasi Awal pada Anak

Gambar 2 menunjukkan bahwa kemampuan awal untuk indikator 1 yaitu anak dapat mendengarkan cerita sudah ditunjukkan lebih dari 50 persen oleh anak di TPA Darma Yoga Santi. Hal ini menunjukkan bahwa kemampuan tersebut sudah mulai muncul dengan baik. Namun untuk indikator 2,3, dan 4 yaitu anak dapat merespon cerita dalam bentuk komentar atau pertanyaan, anak mampu menceritakan cerita sesuai dengan pengalamannya dalam bentuk tulisan berupa gambar/bentuk/huruf, dan anak mampu menceritakan kembali hasil tulisannya masih kurang dari 50 persen. Hasil ini sangat berbeda dengan pertemuan akhir yang terhitung sebagai hasil posttest yaitu semua indikator menunjukkan peningkatan yang signifikan dan mencapai 100 persen. Hasil penelitian ini menunjukkan bahwa LEA dapat meningkatkan literasi awal pada anak usia dini.

\section{Pembahasan}

Hasil penelitian ini diperoleh temuan yaitu pertama, anak-anak tidak memiliki rasa percaya diri ketika harus menuangkan pengalamannya di atas kertas. Kebiasaan menulis dan menuangkan pesan dalam bentuk tulisan perlu menjadi hal utama dalam menumbuhkan literasi pada anak (Soderman \& Farrell, 2008). Berbagai strategi pula harus dilakukan untuk anak melibatkan penggunaan kertas dan alat tulis dari berbagai bentuk dan tekstur. Strategi ini menghantarkan anak untuk tertarik melakukan kegiatan baca tulis di awal kehidupannya. Tidak percaya diri pada anak disebabkan kurangnya guru mengenalkan anak pada pesan tulis menggunakan kertas dan alat tulis. Kepercayaan diri anak tumbuh sejalan dengan seringnya anak bermain dengan kertas dan alat tulis. Hal ini ditunjukkan pada anak dipertemuan hari kedelapan, dimana semua anak sudah terbiasa untuk menuangkan sesuatu dalam bentuk tulisan agar bisa dibaca oleh orang lain.

Kedua, anak-anak membutuhkan penguatan yang terus menerus terkait proses menuangkan pengalamannya dalam bentuk tertulis. Pemberian penguatan pada anak merupakan bukti bahwa proses belajar anak memerlukan dukungan lingkungan yaitu berkaitan dengan pendekatan behavioristik (Hoff, 2009). Pendekatan ini dalam proses perolehan bahasa mengatakan bahwa bahasa dapat diperoleh melalui penguatan yang dilakukan oleh orang disekitar anak. Penguatan yang sungguh-sungguh dari orang sekitar memberi dukungan literasi pada anak.

Ketiga, pentingnya peran guru dalam memberikan contoh perilaku membaca dan menulis di depan anak-anak. Guru berperan sebagai model bagi anak untuk mengembangkan literasi. Peniruan yang dilakukan anak terhadap orang dewasa, meyakinkan bahwa anak membutuhkan contoh untuk dapat melakukan kegiatan literasi. Melalui contoh kegiatan menulis dan membaca di depan anak-anak, meyakinkan anak-anak bahwa tulisan mengandung pesan, dan dapat digunakan sebagai cara untuk berkomunikasi (Brewer, 2008). Pentingnya peran orang dewasa dalam memunculkan minat literasi menyadarkan bahwa akar literasi anak adalah keluarga (Otto, 2015).

Keempat, kosa kata anak ketika bercerita perlu dibantu oleh guru. Keterbatasan kosakata anak ketika bercerita membuktikan bahwa kemampuan bahasa sangat dipengaruhi oleh perkembangan kognitif Piaget dan Vygotsky (Otto, 2015). Teori ini merujuk pada pendapat perolehan bahasa dengan pendekatan perkembangan kognitif. Piaget mengatakan bahwa kemampuan bahasa anak dipengaruhi 
tahapan perkembangan kognitifnya. Kenyataan bahwa anak membutuhkan bantuan karena keterbatasan kosakata juga merupakan pendekatan yang berkaitan dengan jarak ZPD dan pentingnya pemberian bantuan pada masing-masing anak secara individual yang oleh Vygotsky katakan guru atau orang dewasa berperan sebagai scaffolding untuk anak.

Kelima, guru perlu mendapat pelatihan dalam bercerita yang baik. Kaitannya dalam memperoleh pengalaman kebahasaan melalui cerita, guru perlu berlatih menjadi pencerita yang baik. Ketertarikan anak mendengarkan cerita tidak hanya terletak pada penggunaan alat peraga, namun guru merupakan alat peraga yang penting dalam menyampaikan pesan. Guru perlu memahami jalan cerita terlebih dahulu untuk mampu menceritakan sesuatu kepada anak. Pemahaman cerita disebut sebagai tahap awal dalam mempersiapkan kegiatan bercerita untuk anak. Jalongo (2000) mengatakan bahwa pemahaman guru terhadap teks memudahkan guru melakukan improvisasi dalam bercerita dan berpengaruh pula pada anak sebagai pendengar dalam mengelola informasi.

Keenam, lebih mudah bagi anak untuk menceritakan kembali hasil karyanya ketika proses menulis tersebut dilakukan. Anak-anak menunjukkan kemampuan yang lebih baik ketika harus menceritakan hasil karyanya ketika mereka sedang melakukan proses menulis dibandingkan ketika anak harus menceritakannya di depan kelas. Beberapa aspek nonkebahasaan yang mempengaruhi kemampuan bicara merupakan salah satu faktor yang menyebabkan anak sulit untuk menceritakan hasil karyanya didepan banyak orang. Salah satu faktor nonkebahasaan tersebut yaitu keberanian (Dhieni, 2008). Perilaku yang ditunjukkan anak yaitu anak hanya menyebutkan gambar belum mampu menceritakan kembali cerita.

\section{SIMPULAN}

Hasil penelitian diperoleh bahwa penerapan LEA melalui cerita budaya lokal dapat meningkatkan kemampuan literasi awal pada anak di TPA Darma Yoga Santi. Hasil penelitian ini diperoleh temuan yaitu pertama, anak-anak tidak memiliki rasa percaya diri ketika harus menuangkan pengalamannya di atas kertas. Kedua, anak-anak membutuhkan penguatan yang terus menerus terkait proses menuangkan pengalamannya dalam bentuk tertulis. Ketiga, pentingnya peran guru dalam memberikan contoh perilaku membaca dan menulis di depan anak-anak. Keempat, kosa kata anak ketika bercerita perlu dibantu oleh guru. Kelima, guru perlu mendapat pelatihan dalam bercerita yang baik. Keenam, lebih mudah bagi anak untuk menceritakan kembali hasil karyanya ketika proses menulis tersebut dilakukan.

Berdasarkan hasil penelitian, adapun saran yang dapat dilakukan yaitu; (1) Bagi guru, guru perlu memahami dan mendalami cerita terlebih dahulu untuk mampu mennyampaikan pesan pada anak, guru juga berperan menjadi model dalam kegiatan menulis; (2) Bagi peneliti selanjutnya, pendekatan LEA dapat digunakan untuk anak di atas usia 5-6 tahun untuk melihat kemampuan menulis dan menceritakan kembali hasil karyanya terkait dengan penggunaan kosa kata dan beberapa faktor yang menghambat kemampuan bercerita anak.

\section{DAFTAR PUSTAKA}

Beaty, J. J. (2013). Preschool appropriate practices: Environment, curriculum, and development. Cengage Learning.

Bowman, M., \& Treiman, R. (2004). Stepping stones to reading. Theory into Practice, 43(4), 295-303. https://doi.org/10.1207/s15430421tip4304_8

Brewer, J. A. (2007). Early childhood education: Preschool through primary grades. Pearson.

Christianti, M., \& Cholimah, N. (2013). Pengenalan karakter melalui cerita rakyat budaya lokal untuk anak usia dini. Prosiding. Yogyakarta: Universitas Negeri Yogyakarta.

Darnita, D. (2019). Penerapan model tutor sebaya berbasis literasi untuk meningkatkan hasil belajar tematik siswa. Jurnal Riset Teknologi dan Inovasi Pendidikan, 153-166.

Dhieni, N. (2008). Studi penelusuran lulusan program studi pendidikan anak usia dini. Perspektif Ilmu Pendidikan, 17(IX), 83-89. https://doi.org/10.21009/PIP.171.9

Go Bekasi. (2016). Survei UNESCO: Minat baca masyarakat Indonesia 0,001 persen. Diakses dari http://gobekasi.pojoksatu.id/2016/05/19/survei-unesco-minat-baca-masyarakat-indonesia-0001persen/ pada tanggal 13 April 2017. 
Handayani, I. P. (2018). Pengaruh program literasi terhadap prestasi belajar siswa di SMA Negeri 21 Surabaya. Inspirasi Manajemen Pendidikan, 6(3).

Hoff, E. (2009). Language development at an early age: Learning mechanisms and outcomes from birth to five years. Encyclopedia on Early Childhood Development, 1-5. http://www.childencyclopedia.com/language-development-and-literacy/according-experts/languagedevelopment-early-age-learning.

Jalongo, M. R. (2000). Early childhood language arts: Meeting diverse literacy needs through collaboration with families and professionals. Allyn and Bacon, 160 Gould St., Needham Heights, MA 02494.

Kasiyun, S. (2015). Upaya meningkatkan minat baca sebagai sarana untuk mencerdaskan bangsa. Jurnal Pena Indonesia, 1(1), 79-95. http://dx.doi.org/10.26740/jpi.v1n1.p79-95

Kauntur, R. (2018). Metode penelitian untuk penulisan skripsi dan tesis. Jakarta: CV Teruna Grafica.

Kompas. (2016). Minat baca Indonesia ada di urutan 60 dunia. Diakses dari http://edukasi.kompas.com/read/2016/08/29/07175131/minat.baca.indone sia.ada.di.urutan.ke60.dunia pada tanggal 13 April 2017.

Lewis, B. A., Avrich, A. A., Freebairn, L. A., Hansen, A. J., Sucheston, L. E., Kuo, I., ... \& Stein, C. M. (2011). Literacy outcomes of children with early childhood speech sound disorders: Impact of endophenotypes. Journal of Speech, Language, and Hearing Research. 10.1044/10924388(2011/10-0124)

Masengi, A. (2014). Peranan Orang Tua Dalam Mengembangkan Minat Baca Siswa SD Negeri 121 Kecamatan Malalayang Manado. JURNAL ACTA DIURNA, 3(4).

Otto, B. (2015). Perkembangan bahasa pada anak usia dini. Jakarta: Kencana.

Soderman, A. K., \& Farrell, P. (2008). Creating literacy-rich preschools and kindergartens. Allyn \& Bacon. 